\title{
WHEN PEN SWALLOW'S JUSTICE: A STUDY ON RECTIFICATION OF LAWS: ERROR FREE PUBLICATION OF LAWS OF PAKISTAN
}

\author{
Qurrat-Ul-Ain Rehman \\ Cluster Head: Lecturer (Law Department) \\ Bahria University, Shangrilla Road, Sector E-8, \\ Islamabad - Pakistan \\ qrehman.buic@bahria.edu.pk
}

\begin{abstract}
The Supreme Court of Pakistan took Suo moto action and passed an order on 3rd March, 2015 directing that legislation shall be made for the purpose of regulating the publication of law books and keeping a strict eye on the sale of inaccurate law book publically, as it led to adverse consequences. In August, 2015 Supreme Court of Pakistan passed an order directing that notices be issued to Pakistan Bar Council, Provincial Bar Councils as well as Federal Law Ministry and Provincial Law Departments so that the matter of error in publication of law books can be adequately addressed and this serious issue can be properly attended. The committee of government bodies convened its meetings on 21.11 .2014 \& 01.12.2014. It was unanimously of the view that at present no regulatory framework for error free publication of either primary or delegated legislation is available to cater for present issue. The committee, therefore, recommended establishing a separate organization/autonomous body/board or directorate to ensure error free publication of statutes in books and on websites. Extent of jurisdiction Text of books or websites/electronic publication would require certification where the entire Statutes/ Act/ Ordinancel Rules or Regulations have been reproduced after a careful comparison with its authentic and updated version. Publication of law book in Pakistan was a huge disaster because they contained mistakes. The current standards of the Law publications have been highly affected by the inattentiveness of the government and private publishing bodies. The Ministry of law and justice has been advised by the Supreme Court of Pakistan to form a criterion for restriction of cause of error in Law books. In persons thereof a cell namely "The Publication of laws of Pakistan" cell was established by the Ministry under the Ordinance, the Ordinance later on was converted into the Act of the Parliament "The Publication of Laws of Pakistan Act, 2016". Instead of establishing a cell under the supervision and control of Ministry of law and justice it would have been far batter if an independent commission would have established for the realization of purpose.
\end{abstract}

Keywords: Supreme Court, Bar Councils, Sou moto, Laws, Ministry and Pakistan.

\section{INTRODUCTION}

The supreme court of the Islamic Republic of Pakistan released a statement including strong laws to deal with false and inaccurate publishing of laws and regulations to avoid miscommunication amongst the provincial courts. The ministry of Federal law was tasked with making sure they set a mechanism to deal with the publishing and printing of any kind of law based material. Ministry of law and Justice adhered the compliance of the Order by creating a working team. Ministry of Law and Justice, Government of Pakistan, as well as Provincial Law Departments were publishing timely and regularly Annual Collection of Laws, Volumes of Pakistan Code and Provincial Codes and Collections of Statutory Rules and Regulations, etc., immediately after the conclusion of the preceding year of such legislation but Pakistan Code was not considered as accurate source for laws.

Pursuant to the direction of the Supreme Court the resolutions were sought from all four Provincial assemblies under Article 144 of the Constitution. All the Provincial assemblies passed resolution to this affect. On March 29, 2016, late President Mamnoon Hussain assented the bill and converted it into "The Publication of Laws of Pakistan Act, 2016". This law aims to regulate the publication of the books containing the script of the laws free from any error. 
Not to be left out that the Law Ministry is also supposed to keep with them the most updated version of all the laws of the Islamic Republic of Pakistan in both English as well as the national language Urdu and this very piece of information is going to be used to measure, maintain and update the other existing/available books of law. The gazettes of the federal as well as the provincial level are also required to be available with the ministry of law so that any amendment is possible as quickly as possible. (Suo moto Matter regarding publishing/printing incorrect version of Section 23 of Contract Act, 1872 in the Book titled "The Contract Act, 1872, 2nd Edition/2011", 2014)

A series of publishing authorities, law reviewing regarding the translation of laws, ensuring any error is amended by proper channel as well as deleting or adding updated version of laws, confiscating misleading prints regarding laws \& stopping falsely published laws from entering the market. In case of breach of any of the aforementioned stipulations, the publishing personnel under discussion is bound to get punished by either a specific prison time or amounts leading up to PKR 3 Million or a minimum of PKR 2 Million but nothing less. General awareness as well as proper channeling is desperate required to get these serious issues to fade away. The amendments in official websites as well as government institutions to control the regulations is something that will go a long way in terms of propelling law. (Constitution of Islamic Republic of Pakistan, 1973, PK, A.144)

Previously there was a full-fledged Department of the Federal Government namely Stationery and Forms Department under the administrative control of the Cabinet Division which is now abolished and the said Department was responsible for ensuring provision of the Gazette of Pakistan as well as other Federal Government publications to the general public and the Government offices. Even in this age of information technology complete issues of the Gazette of Pakistan as well as Provincial Gazettes are not available on Websites of the concerned Governments as far as hard copies or published forms of laws are not easily accessible and available for general public although there should be exclusive websites containing all issues of Gazette of Pakistan as well as Provincial Gazettes by the relevant Governments and there should be daily updating of such official websites. Only Ministry of Law and Justice after the order of Honorable Supreme Court of Pakistan is working on the above said issue and has developed a website.

But it is also the responsibility of the concerned legislative bodies to get published their Acts in the relevant official Gazettes, Federal or Provincial, as the case may be, but no such facility is available either on their websites or in publication/book form on yearly basis although it is necessary requirement that all legislative bodies should directly provide access to such documents nowadays through their official websites as well as in the form of annual publications/books on reasonable prices to general.

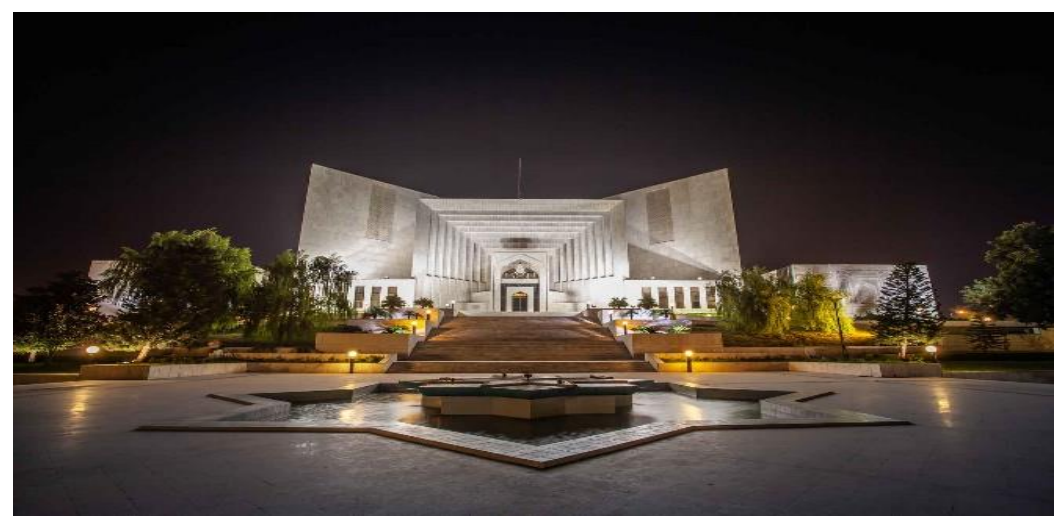

Figure 1 Supreme Court of Pakistan

\section{Reservations of Publishers Regarding Publication of Laws of Pakistan Rules, Ordinance \& Act}

Following are the reservations of publishers regarding Publications of laws of Pakistan which stop publisher not to publish law book without prior approval:

a. That promulgation of such law violates the express command of Article 144 of the constitution of Islamic republic of Pakistan 1973.

b. That the promulgation of such Law pursuant there to fall foul of the requirement of the necessity warranting immediate action as mandated under Article 89 of the constitution. 
c. That such Law violates the letter and spirit of Article 2A of the constitution as interpreted and applied by the superior courts of Pakistan.

d. That the oppressive and the onerous regime of such Laws and the consequent notice violate the constitution due process of law as enshrined in Article 4,5, 8 and 10-A of the constitution.

e. That publication of laws of Pakistan placing unreasonable and onerous restrictions, violate the right to trade, business and profession of private publishers and consumers including the petitioners as enshrined in Article 18 of the constitution.

f. That such Law unreasonable place restrictions, on the "freedom of press" and thus violate the letter spirit and mandate of Article 19 of the constitution.

g. That such Law violates the established tenets of constitution principle of policy, as enshrined in, inter alia, Article 29,30,37, and 38.

h. That such Laws restricts free market competition in violation of established principle of natural justice, and express provisions of the competition commission act 2010.

i. That the Publication of Laws of Pakistan violates the cardinal principle of access to justice, by making the provision of justice more in accessible and expensive for all citizenry.

j. That the provisions of such Laws, in creating a government appointed cell that is a regulator for review of all publications of laws of Pakistan, violate the established principle of our jurisprudence in regards to regulatory capture.

Challenges Faced by Publishers after Promulgation of Publication of Laws of Pakistan Act, 2016 Once the law was passed regarding the Publication of Laws of Pakistan in 2016, unless registered with the cell, the publishers were not allowed to publish any law of Pakistan. The publication suggested by them was bound to be scrutinized by the cell. If up to date and accurate, the cell would issue a certificate after approval. The challenges faced by the Publishers were as following.

Mostly publishers say that this Law is against the principles of natural justice, discriminatory, in violation of the due process of law, the Constitution as well as the letter and spirit of Judgment. The Laws of Pakistan Act, 2016 says each private publisher, who is involved in the publication of laws of Pakistan, is needed to register with the Cell within 3 months of the initiation of the Act, according to the process defined in the act. Consequently, the requirements of registration fee, according to the publishers this rule is not only violates the letter and spirit of the Judgment, but also the express provisions of the Constitutional, and established principles of natural justice, and this is liable to be declared illegal and unconstitutional. The Laws of Pakistan Act, 2016 stipulates that the fee received from reviewing provincial law is to be deposited in the respective province's reserves. in this way which is a subordinate Instrument passed under a Federal Ordinance Impose a fee that is provincial in nature.

The Cell is required to review the laws of Pakistan submitted by respective private publisher, within a maximum period of two months, and issue certified of accuracy. This delay of at least sixty days even after prior review has already been done by the private publisher through private reviewers shall result in ordinate delay in the publication of the laws of Pakistan in the interregnum no publication of the concerned laws of Pakistan can be made by a private publisher. The same amount to an unreasonable restriction on the private publisher's right to trade, business and occupation and would also restrict the timely availability of laws of Pakistan in the private market, where an error is discovered in the publication of the laws of Pakistan by a private publisher, even after the same has been certified by the cell, it is the responsibility of the private publisher to «recall» all such publications for onward transmission of the same to the cell for rectification of the error.

This process shall result in excessive expenditure to be incurred by the private publishers even after such publishers have already discharged all of their obligations under the Act and the mistake has occurred on part of the cell. Private publisher has obtained the requisite certificate of accuracy from the cell and publishers the law of Pakistan such publisher is required to submit twenty copies thereof free of cost to the cell. This requirement in itself is onerous burdensome and expensive for the private publisher and finds to no justification in law or in logic. Consequently, the Act limits the free market competition in the private competition in the private publishing sector, at the peril of criminal and civil penalties.

Case Study 
The Honorable Supreme Court of Pakistan finds a serious problem in the publishing industry. The unavailability, either on an official website or in paper form, of the laws of Pakistan in the form of a consolidated code. It is the responsibility of the state to make the applicable laws easily accessible to the public, but unfortunately it has no basis in Pakistan. It infringes the privileges of the Pakistanis and backs the continuance and spread of lawlessness in the country.

This case attracted the attention of the Court and opinions were given to the Councils of Lawyers, as well as to certain authors and publishers of books containing errors.

"Since the case concerns the printing of law books, etc., therefore, the respective bar councils under their jurisdiction authorized under the Legal Professionals and Bar Councils Act 1973 will be free to take action if such documents are provided to them, therefore, the aforementioned petitions are resolved."

From the following discussion, legal advice or even the federal and provincial governments did not address the important legal issues mentioned above, since no action seems to have been taken since the transfer of the aforementioned cases.

The incident which compels the Judges to give judgments which stop publishers to publish error full books is as follows:

"The judges of the Honorable Supreme Court of Pakistan heard a case, if the judges were informed that a major omission had been made in Article 23 of the Contract Law published by Al Qanun Publishers and drawn up by M. Judges of the Honorable Supreme Court of Pakistan asked the librarian to investigate the matter and present a report. When the judges read their report, the various legal councils and the federal and provincial governments were advised to take initiatives in this matter. It is puzzling that they have not taken no measure to remedy the dire situation and that the Bar Councils have not done so despite the ordinance."

Over time, the Honorable Supreme Court again took steps to resolve this matter as follows:

The Supreme Court again issued rulings to the legal councils as well as to the Federal and Provincial Legal Services. On November 19, 2014, the judges of the Supreme Court of Pakistan asked the learned Attorney General to inform them if there is an operational mechanism or law to ensure the publication of law books is properly regulated and they also asked him to verify if there is any law which imposed civil or criminal liability on publishers, authors, etc. Neither the legal councils nor the federal or provincial governments have shown any serious intention to address what is clearly a major problem. This is strange to the judges not finding any certified publication, handwritten, printed or in the form of a soft copy, that has a precise and immaculate version of the laws of Pakistan in an easily accessible compilation. As such, there are no simple and user-friendly ways available to the Pakistani people to let them know what the law book contains.

\section{CONCLUSIONS}

The Supreme Court of Pakistan ordered the Federal Ministry of Law's Secretary to develop such a framework / legislation to control the publication of legal books and documents along with bringing to a halt, the widespread threat that erroneous law books will be sold to the public and to the lawyers. And also order that the enforcement mechanism be created to stop the publication of erroneous law books. The Ministry of Law is set up by the Supreme Court of Pakistan to deal with this uphill job. Supreme Court lays focus on the government to ensure every sort of law is readily available to make sure law and order is not breached which ultimately means citizens can get justice served at the minimal of hassle

The laws were thereby supposed to be available in all possible languages at all times under Article 251of the Islamic Republic if Pakistan and it was a big worry which at times caused confusion to deal in the simplest of circumstances, in accordance with the constitutional provision of Article 28 of the Constitution of the Islamic Republic of Pakistan. As soon as a change or amendment is made to a legislative or regulatory text, etc., revised editions of these publications should be published. Also, the footnote / endnote must be complete and disclose all the information about the document that is used 


\section{REFERENCES}

Suo moto Matter regarding publishing/printing incorrect version of Section 23 of Contract Act, 1872 in the Book titled "The Contract Act, 1872, 2nd Edition/2011" by M. Mahmood, Advocate [2014] PKSC C.M.A 4343. Retrieved from http://www.supremecourt.gov.pk/web/user files/File/c.m.a.4343 2014 etc with urdu transla tion.pdf.

Constitution of Islamic Republic of Pakistan ,1973 (PK) Retrieved from http://na.gov.pk/uploads/documents/1333523681_951.pdf

Obscene Publications Act, 1959 (UK) Retrieved from https://www.iwf.org.uk/hotline/thelaws/criminally-obscene-adult-content/obscene-publications-act-1959-and-1964

Ministry: Information and Broadcasting. [2011]. The Press and Registration of Books and Publications Bill, 2011. PRS legislative research. Retrieved from http://www.prsindia.org/uploads/media/Press/Press\%20and\%20Registration\%20of\%20Books \%20and\%20Publications\%20Bill\%202011.pdf

Copyright.gov. [n.d.]. Chapter 1: Subject Matter and Scope of Copyright. Retrieved from http://www.copyright.gov/title17/circ92.pdf 